\title{
Development of Creativity of Students in Higher Educational Institutions: Assessment of Students and Experts
}

\author{
Alena D. Matraeva ${ }^{1, *}$, Marina V. Rybakova ${ }^{1}$, Mikhail V. Vinichenko ${ }^{2}$, Aleksander A. Oseev ${ }^{3}$, \\ Natalia V. Ljapunova ${ }^{4}$ \\ ${ }^{1}$ Department of Management Sociology, Lomonosov Moscow State University, Russia \\ ${ }^{2}$ Department of Personnel Management and Personnel Policy, Russian State Social University, Russia \\ ${ }^{3}$ Department of Economic Sociology and Management Sociology, Lomonosov Moscow State University, Russia \\ ${ }^{4}$ Department of History, Russian State Social University, Russia
}

Received September 3, 2019; Revised November 28, 2019; Accepted December 4, 2019

Copyright $\mathrm{C} 2020$ by authors, all rights reserved. Authors agree that this article remains permanently open access under the terms of the Creative Commons Attribution License 4.0 International License

\begin{abstract}
The aim of the article is to identify the conditions of the development of students' creativity in the process of studying in higher education institutions. The article draws on the results of authors' qualitative and quantitative studies. Qualitative research is represented by expert in-depth interviews with specialists in the field of higher education. Quantitative research consists of questionnaire of students of four Moscow higher education institutions. Analysis of recent studies conducted on the topics of youth employment, higher education, the problem of mismatch between the education system and labor market was used. The article shows that in the context of higher education, creativity is considered as an integrative property, the key characteristics of which are the ability to produce original ideas, result-orientation, solution of practical problems, originality and speed of thinking, openness to new experience, and tolerance for uncertainty. The authors have identified the factors, conditions and levels of the process of creativity development of students in higher education institutions and analyzed its content. According to the authors, the defining contribution to the development of students' creativity is the application of a comprehensive, systemic concept at a higher education institution in accordance with three distinguished levels: personal, procedural and environmental.
\end{abstract}

Keywords Creativity, Education, Students, Higher Education Institutions

\section{Introduction}

The relevance of the research of development of creativity of modern Russian students is connected with the transformations taking place in the economic, political, social and cultural spheres of society, the tendency to transition to a "knowledge society", increasing value of education and science in the modern world, an increase in employers' requirements for the level and quality of training of employees[1]. Creativity is one of the most popular subjects of research of sociologists, specialists in psychology, management [2]. The importance of such studies cannot be overestimated, since the formation and development of the post-industrial economy is based on the production of innovative products and new ideas. The basis for the production of any product or ideas is the result of the application of human abilities and skills. Therefore, the development of creativity is a prerequisite for the financial and social success of the company in the market, and at the state, world level - the competitiveness of national economies.

Interest in the development of creativity is formed in various spheres. Thus, in the Human Development Report (UNDP) identified the key human qualities of the 21st century, among which creativity is one of the qualities that form the model of the " $4 \mathrm{C}$ " - critical thinking, collaboration, creativity, and communication [3]. The International Labor Organization identifies creativity as one of the main skills needed in modern life, and emphasizes the need of the development of creativity as part of its integration into the process of academic education and professional training [4]. Russian and international labor market research, the nature of the demand for professionals demonstrate the relevance of the skills and human qualities such as creativity, ability to work in a team and independently, solving problems, skills in searching for new ways of 
development, critical analysis of information, openness to new experience, responsibility for making decisions. There is also an appeal to the problems of creativity at the state level. National Advisory Committee on Creative and Cultural Education is being established in the UK [5]. The frequency of using the term "creativity" increases in the development plans of the Chinese economy, the importance and necessity of changes in the national education system is emphasized to ensure the effective development of creativity among students in academic institutions [6].

\subsection{Conceptualization of the Notion of Creativity}

At the present stage of the development of society, one of the main functions of education is the development of human capital, as the most important resource of the modern economy. Despite the fact that one of the key factors of human capital growth is its creative element, science has not yet formed a consensus about the conceptualization of the notion of creativity.

Guilford defines creativity as a multipurpose cognitive creative ability, highlighting its four main characteristics: fluency, flexibility, accuracy and originality [7]. Torrance, continuing and developing the ideas of Guilford, defines creativity as the process of manifestation of sensitivity to problems, lack of knowledge, disharmony, searching for answers and solutions, promotion of hypotheses, their verification and the formation of results [8]. Maslow considers creativity in connection with the needs of the individual: the higher is the level of demand, the higher is creativity. Creativity is inherent in every person, but most people lose it as a result of the influence of various factors [9]. The connection between creativity and social values is emphasized by Rogers. According to the scientist, one of the most important and leading needs and values of a person is the desire for self-development, self-expression, and development of potential. Openness to the new, the ability to non-standard solutions, the security of the external environment, freedom of self-expression are conditions for the realization of potential, self-development [10]. Csikszentmihalyi notes that creativity is always specific to a particular area; experts determine what is considered to be useful and new in this field. The creative act consists of three systems: the individual, the field of activity (general practices, values, knowledge) and the expert community, that is, the society of people who carry out their professional activities in this field [11]. Simonton suggests that the basis of creativity is the production of a number of ideas, which may be options for solving a particular problem. On the basis of experience and knowledge, a person selects the most appropriate solutions, which eventually becomes a final product [12]. Simonton also argues the creative ideas cannot be defined without defining uncreative ideas with application of certain measurement parameters [13]. Of course, for the implementation of this kind of process, not only experience and knowledge are needed, but also a number of certain abilities and qualities. In addition, there are approaches to the definition of creativity, incorporating a set of previously formulated definitions: "Creativity is a fusion of perceptions implemented in a new way (McCullar), the ability to find new connections (Cubie), the emergence of new relationships (Rogers), the predisposition to make and recognize innovations (Lassuelle), the activity of the mind, leading to new insights (Gerard), transformation experience in a new organization, the imagination of new constellations of meanings (Giselin)" [14].

\subsection{Creativity and Education}

In the context of education, creativity can be viewed from various perspectives. One of the approaches to the study of creativity in education is related to the introduction of a competence approach and is based on the consideration of creativity as the correlation of several structural components: methodological, procedural, personal, and panoramic [15]. Under this approach, creative competence is defined as the ability to effectively and inventive work, actualized knowledge and experience in conditions of uncertainty with the aim of solving specific practical problems, readiness for the adaptive use of acquired knowledge, self-education and self-improvement [16]. Depending on the subject, creativity in education is studied in four aspects: personal (the creativity of staff and students), group (communication, cooperation), procedural, institutional (factors and environmental conditions) [17].

In all studies, which in any way affect the question of development skills and personality traits that are associated with creativity, noticed the importance of the culture, environment and other conditions. Development of the creative economy, human capital and stimulating innovations requires collaboration between higher education, economy, and cultural policies [18]. John Baer states that skills, knowledge, attitudes do not develop in a vacuum, they always vary by domain, so the question about development of creativity firstly is a question of domains to be used [19]. Research conducted on the issue of creativity of collaborative teams indicated that closeness can be beneficial for group creativity when perspective taking is not included [20]. The major possibilities for developing creativity during university studies are teaching activities and supportive climate, study program [21].

A number of researchers are concerned that, despite the fact that higher education institutions play a key role in a transforming world, modern educational programs do not meet the needs of the economy and the labour market, the development of creativity is underestimated and is not studied enough, the creative capacity of higher education institutions represent an underused resource of the knowledge-based economy $[22,23]$. As a solution to this 
problem, the authors suggest using transdisciplinary educational approaches $[24,25]$, to include trainings on a creative thinking [26], research experience [27] in the curriculums. Soon Ye Hwang, while analysing creativity as it is traditionally included into educational practices, argues that the creativity should be understood as a fundamental principle of human existence and everyday experience, so such approach will encourage rethinking of creativity in education [28].

Creativity of students has a connection with the creativity of teachers. Teachers' level of creativity is related to how they rate student characteristics associated with creativity, i.e. the more creative teacher is the more desirable he finds the students' characteristics associated with creativity [29]. Moreover, the type of leadership of a teacher and his perception of students is also associated with creativity [30]. There is difference between students' and professors' perception and understanding of creativity. While students mainly define creativity as the characteristic of a person or process [31] the professors understand student creativity through expression of self-reflections, independent decisions, curiosity and motivation, producing and developing something new [32]. The research dedicated to exploring of the perceptions and views of creativity amongst architecture and product design tutors and design students indicated the difference how tutors and students conceptualize creativity. The results also showed the students acknowledge of great influence of tutors and socio-cultural systems both in promoting culture of creativity $[33,34]$. Due to the fact that students' creativity is a central issue in pedagogy, the importance of teachers' creativity is greatly underestimated. At the same time, teachers play one of the most important roles in the educational process; therefore, this issue should not be ignored in the process of teacher training [35]. Trainings have impact on the production of ideas, creativeness of solutions, and effectiveness of leadership [36]. The introduction of learning methods in learning reveals the creative potential of the trainees [37].

\subsection{Problem Statement}

In the modern world, those specialists who are able to generate new ideas, are in high demand, form innovative models and propose and implement competitive projects. The success of such an activity is mainly ensured by the high level of creativity in such specialists. Government and business representatives, not without reason, expect to get workers for decent, well-paid jobs from among young specialists and university graduates. The great creative potential of young people, competently and methodologically designed and implemented, brings great dividends to employers [38]. However, in universities, it is not always possible to timely identify and skillfully form a vector for the development of students' creativity. The problem arises of matching the needs of the labor market, including specific employers, in obtaining creative specialists from higher education institutions and insufficiently developed mechanisms for the formation and development of creative potential in students in the framework of performing labor functions in the chosen specialties and areas of training. As a particular problem in this matter, one can mention the mismatch between the understanding of creativity by all participants in both the educational and labor processes.

The ongoing research on this issue, unfortunately, has not revealed the real mechanisms, causes and factors determining the solution to this problem. A number of researchers consider ways to solve the problem due to the continuity of training in the multitasking mode of uncertainty [39], as well as the development of proactivity, orientation to results and willingness to receive additional education and skills [40]. The problem of the mismatch between the education system and the needs of the labor market is raised [41]. Employers bring up the lack of practical skills among graduates of Russian universities [42] and graduates themselves have a low opinion on the development of their creativity and willingness to actively engage in the labor process. Only a small part of them $(13 \%)$ believes that the knowledge and skills acquired at the university are enough [43]. Moreover, studies suggest that it is soft skills, including creativity, that provide $85 \%$ of career success [44].

The high need for active, creative young specialists in the labor market and the lack of well-established mechanisms for identifying and developing creativity among students made this study necessary.

\section{Research Goal}

The goal of the research is to investigate the state and nature of the development of student creativity in the learning process in higher education from the perspective of students and the expert community.

\section{Research Tasks}

In accordance with the goal of the research, the following research tasks were formulated:

1. To reveal the conditions and factors for the development of creativity of students in the learning process in higher education institutions;

2. To describe the state of the development of creativity of students in universities.

\section{Research Methods}

To identify the state and nature of the development of students' creativity in the learning process in higher education institutions, experts were involved, including 
government officials responsible for training, as well as those who assess the level of training of graduates when they enter the labor market. Their activities are directly related to the creation of conditions and application of technologies for the development of the creative potential of young people. The experts also included representatives of the faculty, which directly train personnel, determining and developing creativity in students. All of them are specialists in the field of higher education.

Objective indicators of the expert group:

- position: chief, deputy Head of Department of the Federal Agency of Scientific Organizations, Ministry of Economic Development - 4; chief, deputy Head of Department of the Ministry of Education and Science - 4; professor, university lecturer -7 ;

- $\quad$ age of experts: up to 30 years - 1;30-39 years old - 3; 40-49 years old $-5 ; 50$ years and older -6 ;

- $\quad$ work experience of experts: less than 5 years - 1; 5-7 years $-2 ; 8$ and more years -12 ;

- distribution of experts by sex: men - 10; women -5 .

In-depth semi-structured interviews were conducted with the experts, allowing revealing their opinion on the state and nature of the development of student creativity in the learning process in higher education institutions.

In the student community, students of those areas of training participated in the survey, which require creativity in professional activities. These were students of four higher education institutions: the Mendeleev University of Chemical Technology of Russia, Lomonosov Moscow State University, Moscow Institute of Physics and Technology and Moscow State Tchaikovsky Conservatory.

In total 587 students were interviewed, of which 164 students of 4th, 5th year specialty "Chemical technology" of D. Mendeleev University of Chemical Technology of Russia, 164 students of the 4th, 5th year of the specialty "Chemical technology" of Lomonosov Moscow State University, 164 students of the 4th and 5th courses of the Faculty of Molecular and Chemical Physics of Moscow Institute of Physics and Technology, 95 students of the 4th course of Moscow State Tchaikovsky Conservatory.

In order to determine students' opinions, a survey was conducted allowing technologically, anonymously and in a short time revealing their opinion on the state and nature of the development of student creativity in the learning process.

\section{Findings}

1) The importance of the development of student creativity is highly valued by experts. Creativity, according to experts, is important, first of all, for solving the main problem of modern society creating a new type of production based on the information and knowledge economy, the essence of which is the creation and development of innovative technologies, goods, works, services.

Experts agree that creativity is necessary for a person as a quality inherent in mobile professionals in demand in the modern labor market, which requires a combination of fundamental knowledge, highly specialized skills and universal human qualities. Experts emphasized that the restriction within the specialty calls into question the general level of the student's preparation, since many scientific achievements lie in the interdisciplinary field.

It is significant that despite the fact that in general experts assess the level of development of modern Russian science and education as insufficient. They believe that the role of education and higher education institutions is extremely important in the process of creating and integrating new knowledge into production processes. Realization of such trends as technical modernization, import substitution, decentralization of production is possible only under certain social and economic conditions directly dependent on higher education: "... its own technological capacities can only be provided if young specialists come with innovative ideas."

The experts who participated in the study formulated the main problem that underlies the education crisis that arose as a result of global changes in the economy, production, science, and technology-the discrepancy between the education system and the social, cultural, political, and economic conditions of life. According to experts, many of the implemented standards in higher education do not correspond to the needs of modern society. In addition, the unstable position of the education system is associated with the lack of a systematic, conceptual approach to education.

The quality of Russian higher education in other studies conducted on this topic has not been highly appreciated. Thus, the results of a survey conducted by the Public Opinion Foundation show that $48 \%$ of respondents assess the quality of Russian higher education as satisfactory, 23\% as poor, and only $12 \%$ as good [45]. According to the information received by the Russian Public Opinion Research Center, the level of training of graduates is changing for the worse; graduates have fewer opportunities to get a job in their specialty. According to analysts, the system of higher education reacts poorly to changes in modern society, without changing anything in the educational process and without helping students in practice apply knowledge in practice [46].

At the same time, experts note that, despite the increasing value of the creative abilities of professionals, accelerating the processes of globalization in all spheres of society, creativity should be developed on the basis of the obtained fundamental education, to be an essential complement to the skills. The Public Opinion Foundation study on ways of development of higher education also shows that the expert opinions of the management of universities and business leaders agree that modern higher education should be both fundamental and more practical, 
oriented to the development of applied skills required by the modern labor market. Also, the distribution of answers to the question concerning the correspondence of modern Russian higher education is indicative: $51 \%$ of employers believe that education needs changes, does not correspond to the economy and the needs of society in the 21 st century [47].

Experts believe that the development of students' creativity is a multi-factor process, which includes many factors and conditions that are inextricably linked. Experts refer to the use of interactive, playful, training methods and forms in the educational process as a significant factor in the development of students' creativity. The most effective of these methods and forms, according to experts, are methods that are as close to practical activities: applied tasks, cases, business games, conferences, strategic sessions, coaching, business talks, seminars, conferences. In addition, the experts formulated a proposal concerning the execution of business plans, strategies as a coursework, diploma, qualification works, and their subsequent evaluation not only by teachers, but also by experts and specialists in a particular field.

One of the highest potentials for the development of creativity has scientific and research work of students, in which practice-oriented, problem approach is the most fully realized. The research activity of universities is one of the key elements, along with the activities of scientific institutes and organizations, in the mechanism of production and the accumulation of new knowledge. At the same time, all experts are concerned about the lack of attention to scientific activity, the lack of investment in science: "science is not paid the amount of attention that it develops at the level of either Europe or the world".

The next significant factor experts called the study of disciplines of the humanitarian profile. Creativity, in the opinion of experts, is inseparable from the value, ideological component of the personality, which is heavily influenced by humanitarian disciplines. Experts noted that the study of humanitarian disciplines develops the capacity for creative thinking, raises the cultural level, and shapes the human value-semantic base.

A significant factor in the development of creativity experts called interpersonal interaction, especially with teachers. Experts believe that the effectiveness of the educational process depends on how much the teacher is interested in professional activities, because the attitude of students, the involvement in the educational process is in correlation with the personal and professional qualities of the teacher: "the youth is involved through the mentor", "the best form of training - do like me", "Effective impact at the level of a person, in this case a teacher - is the most correct level when a person gives something to others. "

The importance of personal influence due to the fact that, despite the trend of development of society and the economy at the present stage is to innovation, the labor market requires professionals with those developed at the appropriate level of skills as the production of ideas and strategies, originality of thought, the ability to analyze, synthesize information and decision-making, the change in educational processes at a global, systemic level, is difficult to implement for a number of reasons. At the same time, it seems possible to carry out a fragmentary impact on the personal level: "creativity is a contribution to the future, the system does not have incentives, there are individuals", "it is necessary to revise the university model, to stimulate innovative projects".

Another important factor in the development of creativity in higher education experts called the creation of conditions in the university environment, contributing to the stimulation of creative processes. Experts note that the process of development of creativity must necessarily include the creation of conditions consisting of social reinforcement of creativity, communication with people with creative abilities, the presence of a positive pattern of creative behavior. The experts referred to such conditions events that provide interpersonal, intergroup communication of participants: excursions to enterprises, organizations, meetings with experts, conferences, round tables.

Experts see a solution to the problem of inconsistency in the quality of student preparation and labor market requirements in an integrated approach, including monitoring the needs and structure of the labor market, educational programs, continuous cooperation of all participants of this process: the state, educational institutions, employer companies, employment centers.

Table 1. Assessment of the degree of development of qualities

\begin{tabular}{|c|l|c|}
\hline \multicolumn{2}{|l|}{ Quality } & $\begin{array}{c}\text { Average } \\
\text { score }\end{array}$ \\
\hline 1 & $\begin{array}{l}\text { ability to produce a variety of original ideas and } \\
\text { strategies that are radically different from the } \\
\text { obvious, common, stereotypical }\end{array}$ & 4,27 \\
\hline 2 & openness to new experiences & 4,11 \\
\hline 3 & individualism & 4,09 \\
\hline 4 & $\begin{array}{l}\text { ability to abandon stereotypical ways of solving } \\
\text { problems }\end{array}$ & 4,02 \\
\hline 5 & willingness to work in an unusual context & 3,86 \\
\hline 6 & $\begin{array}{l}\text { tolerance for uncertainty, rapidly changing } \\
\text { circumstances }\end{array}$ & 3,80 \\
\hline 7 & risk appetite & 3,77 \\
\hline 8 & ability to elaborate ideas & 3,72 \\
\hline 9 & ability to predict & 3,54 \\
\hline 10 & open-mindedness & 3,52 \\
\hline 11 & ability to analyze, synthesis, decision making & 3,49 \\
\hline 12 & $\begin{array}{l}\text { ability to notice and highlight problems, lack or } \\
\text { inconsistency of knowledge }\end{array}$ & 3,49 \\
\hline 13 & $\begin{array}{l}\text { ability to notice unusual details, contradictions } \\
\text { and uncertainties }\end{array}$ & 3,28 \\
\hline 14 & propensity for symbolic, associative thinking & 2,86 \\
\hline 15 & $\begin{array}{l}\text { ability to notice unusual details, contradictions } \\
\text { and uncertainties }\end{array}$ & 2,85 \\
\hline & & \\
\hline
\end{tabular}


2) Students were asked to formulate and assess the extent of quality development that are meaningful elements of creativity. Table 01 shows the average assessment by respondents of the development of a particular quality. The qualities in the table range from most developed to least developed. The average score is 3,6 on a five-point scale. According to the Table 01 it can be seen that the most developed are such qualities as the ability to abandon stereotypical ways of solving problems, openness to new experience, individualism.

Students did not rate any of the proposed qualities as fully developed. Underdeveloped students named such important qualities as a tendency toward symbolic, associative thinking, the ability to notice unusual details, contradictions, and uncertainties (average score 2,86 and $2,85)$.

The analysis of the opinions of students of creative professions allows establishing that the academic environment is focused on developing, as a rule, those qualities that are naturally characteristic of young people, including openness to new impressions, ability to abandon stereotypical ways of solving problems, willingness to work in an unusual context and risk appetite. In this case, synergistic effects may be observed due to the joint concentration of efforts on these qualities of future specialists. However, at the research stage, the faculty was able to achieve only the level of 3.77-4.11. This suggests insufficiently effective methods for the development of creativity. In favor of teachers, one can single out the most developed quality among students - the ability to create many original ideas and strategies that are radically different from obvious, general, stereotyped ones. However, this quality can work in a negative direction without systematic thinking and knowledge of technologies for its implementation.

The majority of students surveyed (78\%) believe that the education they receive contributes to the development of creativity. The process of creativity development is very complicated and the period of study is its essential stage. However, it becomes obvious that at the present stage, education cannot fully create the conditions for development of creativity at the proper level. This is correlated with the results of research by Russian scientists [48].

Analysis of students' answers to the question regarding the development of creativity in the process of studying at the university allows us to conclude that at the university creativity is shaped and developed mainly due to interactive forms of employment and direct social interaction with other participants of the educational process (Table 02). This conclusion is confirmed by the results of the study of the nature of the influence on the quality and stealth of interactive forms of conducting classes [49].
Table 2. Distribution of answers to the question "Who or what is more conducive to the development of creativity in the learning process at the university?’'

\begin{tabular}{|c|l|c|}
\hline & Answer option & $\begin{array}{c}\text { Value } \\
(\%)\end{array}$ \\
\hline 1 & Professors & 21 \\
\hline 2 & Practical trainings & 15 \\
\hline 3 & $\begin{array}{l}\text { Meetings with representatives of companies } \\
\text { and industries }\end{array}$ & 12,6 \\
\hline 4 & Disciplines taught & 12 \\
\hline 5 & Student group & 10 \\
\hline 6 & Research activities & 9 \\
\hline 7 & Participation in student events, organizations & 7,1 \\
\hline 8 & Laboratory works & 4 \\
\hline 9 & Seminars & 3,9 \\
\hline 10 & Lectures & 3,7 \\
\hline 11 & Coursework & 1,7 \\
\hline
\end{tabular}

The analysis of the table data shows that teachers are the basis for the development of creativity in students. This indicator is significantly ahead of others. This means that the creative potential inherent in young people requires its competent disclosure with the help of specialists and technological development. This fact is associated with the need for a more thorough and demanding selection of teachers, as well as training them in the technology of working with students, aimed at identifying creativity and targeted, individual approach to creative talent. In their work, it is advisable for teachers to use more practical exercises with elements of gamification that develop the creativity of student thinking.

It should be noted that high enough students rated "participation in student organizations", "meetings with representatives of Russian and foreign companies, state and public organizations, "expert workshops". These results make it clear that face-to-face learning, contact with the teacher and other participants in the educational process are one of the main sources of learning and self-development. Students also learn from each other, processing new knowledge gained from their own experience. This aspect is very important, as students have a pronounced individuality, in which the exchange of knowledge is not copying, but becomes a creative process.

Table 3. Distribution of answers to the question "Distribution of answers to the question "Which forms of studies at the university are more conducive to the development of creativity?"

\begin{tabular}{|c|c|c|}
\hline & Answer option & Value (\%) \\
\hline 1 & Practice & 23 \\
\hline 2 & Research work & 19,9 \\
\hline 3 & Project Activities & 17 \\
\hline 4 & Business games & 17 \\
\hline 5 & Laboratory works & 11 \\
\hline 6 & Seminars & 7 \\
\hline 7 & Lectures & 3,7 \\
\hline 8 & Coursework & 2 \\
\hline
\end{tabular}


Practice, research activities, project activities, business games are the most useful forms of educational activities which contribute to the development of creativity (Table 03).

Lectures, coursework and laboratory work, which are traditionally used in the educational process, were not evaluated by students as effective for the development of creativity.

\section{Conclusions}

The study has revealed that the process of formation of students' creativity occurs under the influence of a group of factors in certain conditions. First of all, these are the very conditions of studying at university. The degree of students' creativity depends on the academic atmosphere and involvement in creative work. The conditions for the formation of creativity also include the interdisciplinarity of scientific research, which requires coordination of creative processes during the development of fundamental knowledge, highly specialized skills and universal human qualities. The necessity of developing creativity on the basis of the resulting fundamental education has been revealed. Creativity should be an integral complement to professional skills. It has been noted that the study of humanitarian disciplines contributes to the development of creativity since creativity is inseparable from the value, worldview component of the personality.

The research work of students has a high potential for the development of creativity in almost all scientific fields. The most important condition, in which the development of students' creative potential occurs, is a mismatch between the education system and social, cultural, political and economic conditions of life. As the study has shown, in the conditions of instability of the education system and its priorities, the development of students' creativity is significantly hampered. The analysis of university practice has made it possible to identify the most effective methods of increasing creativity in students during classes. These include interactive, gaming, training methods and forms of classes. The leading place in the achievement of goals of the development of creativity, according to students, is taken by teachers, their professionalism. Interpersonal interaction with them motivates students to create innovative projects. The creative communication environment at events in universities, enterprises, exhibitions and conferences allows one to develop a taste for this type of student activity.

Thus, the development of students' creativity is one of the main goals of the activities of university teachers. The nature and degree of development of student creativity depend on their skill, personal creativity, as well as the application of innovative methods and forms of conducting classes. The ability to captivate students with research work also lies in the plane of increasing motivation for the development of creativity. Moreover, university administration should comprehensively approach the development of creativity in all areas and at all levels of management, creating favorable conditions for the creativity of the educational process.

\section{REFERENCES}

[1] M. V. Vinichenko, O. L. Chulanova, S. V. Bolotov, A. V. Melnichuk, Y. A. Melnichuk. Forming a Competence Model in the Course of Volunteer Activities of Students to include them into the Organization's Personnel Reserve. International Journal of Engineering \& Technology, Vol. 7 No. 4.38, 632-635, 2018.

[2] N. V. Buley, T. S. Demchenko, S. A. Makushkin, M. V. Vinichenko, A.V. Melnichuk. Human resource management in the context of the global economic crisis. International Journal of Economics and Financial Issues, Vol. 6, No. 8S, 160-165, 2016.

[3] National Human Development Report 2018. Online available from http://hdr.undp.org/en/year/2018 Accessed date 03.10.2018.

[4] Policy Brief: Enhancing youth employability: The importance of core work skills. 2013. Online available from http://www.ilo.org/skills/pubs/WCMS_234467/lang--en/in dex.htm Accessed date 03.10.2018.

[5] National Advisory Committee on Creative and Cultural Education. All Our Futures: Creativity, Culture and Education. London. 1999. Online available from http://files.eric.ed.gov/fulltext/ED440037.pdf Accessed date 03.10 .2018 .

[6] W. Pang, J. A. Plucker. Recent Transformations in China's Economic, Social, and Education Policies for Promoting Innovation and Creativity. The Journal of Creative Behavior, Vol. 46, No. 4, 247-273, 2012. doi: 10.1002/jocb.17

[7] J. Guilford. Three sides of intelligence. Psychology of thinking. Progress, Moscow, 14, 1965.

[8] E. P. Torrance. The Nature of Creativity as Manifest in the Testing. The Nature of Creativity. Camb. Press, Cambridge, 43-75, 1998.

[9] A. H. Maslow. The Far Limits of the Human Psyche. St. Petersburg, 432, 1999.

[10] C. R. Rogers. A look at psychotherapy. The formation of man. Publishing group "Progress", "Univers", Moscow, 480, 1994.

[11] M. Csikszentmihalyi. Creativity: Flow and the Psychology of Discovery and Invention. Harper Collins Publishers, New York, 456, 1996.

[12] D. K. Simonton. The creative process in Picasso's Guernica sketches: Monotonic improvements versus nonmonotonic variants. Creativity Research Journal, Vol. 19, No. 4, 329-344, 2007. doi: 10.1080/10400410701753291 
[13] D. K. Simonton. Defining Creativity: Don't We Also Need to Define What Is Not Creative? Journal of Creative Behavior, Vol. 52, No. 1, 80-90, 2018. doi: 10.1002/jocb.137

[14] R. J. Hallmann. The necessary and sufficient conditions of creativity. Journal of Humanistic Psychology, 20, 1963.

[15] J. Erpenbeck, M. Sauer. Das Forschungs-und Entwicklungsprogramm «Lernkultur

Kompetenzentwicklung». Arbeitsgemeinschaft Qualifikations-Entwicklungs-Management (Hrsg.): Kompetenzentwicklung 2000: Lernen im Wandel - Wandel durch Lernen. Munster. 2000.

[16] R. Epstein. Generativity theory and creativity. M. A. Runco \& R. S. Albert (Eds.), Theories of creativity (Rev. ed.) Hampton Press, Cresskill, NJ, 2005.

[17] Creativity in higher education. Report on the EUA Creativity Project. 2007. Online available from https://eua.eu/downlo ads/publications/creativity\%20in\%20higher\%20education $\% 20-\% 20$ report $\% 20$ on $\% 20$ the $\% 20$ eua $\% 20$ creativity $\% 20$ pr oject $\% 202006-2007$.pdf Accessed date 03.10.2018.

[18] A. Gilmore, R. Comunian. Beyond the campus: higher education, cultural policy and the creative economy, International Journal of Cultural Policy, Vol. 22, No. 1, 1-9, 2016. doi: 10.1080/10286632.2015.1101089

[19] J. Baer. Creativity Doesn't Develop in a Vacuum. New Directions for Child and Adolescent Development, Special Issue: Perspectives on Creativity Development, Vol. 151, 9-20, 2016. doi: 10.1002/cad.20151

[20] P. Oztop, K. Katsikopoulos, M. Gummerum. Creativity through Connectedness: The Role of Closeness and Perspective Taking in Group Creativity. Creativity Research Journal, Vol. 30, No. 3, 266-275, 2018. doi: 10.1080/10400419.2018.1488347

[21] B. Goldsmith, R. Bridgstock. Creative graduate pathways within and beyond the creative industries. Journal of Education and Work, Vol. 28, No. 4, 369-387, 2015. doi: $10.1080 / 13639080.2014 .997684$

[22] D. Valgeirsdottir, B. Onarheim, G. Gabrielsen. Product creativity assessment of innovations: considering the creative process. International Journal of Design Creativity and Innovation, Vol. 3, No. 2, 95-106, 2015. doi: $10.1080 / 21650349.2014 .954626$

[23] S. B. Maksić, V. Z. Spasenović. Educational Science Students' Implicit Theories of Creativity. Creativity Research Journal, Vol. 30, No. 3, 287-294, 2018. doi: $10.1080 / 10400419.2018 .1488200$

[24] O. Mould, T. Vorley, R. Roodhouse. Realizing capabilities - academic creativity and the creative industries. Creative Industries Journal, Vol. 1, No. 2, 137-150, 2009.

[25] M. A. Peters. Competing Conceptions of the Creative University. Educational Philosophy and Theory, Vol. 46, No. 7, 713-717, 2014. doi: 10.1080/00131857.2013.785074

[26] G. Bocchi, E. Cianci, A. Montuori, R. Trigona, O. Nicolaus. Educating for Creativity. World Futures, Vol. 70, No. 5, 336-369, 2014. doi: 10.1080/02604027.2014.977084

[27] R. P. Schlee, K. R. Harich. Teaching Creativity to Business Students: How Well Are We Doing? Journal of Education for Business, Vol. 89, No. 3, 133-141, 2014. doi: 10.1080/08832323.2013.781987

[28] M. Munakata, A. Vaidya. Fostering Creativity through Personalized Education. Problems, Resources, and Issues in Mathematics Undergraduate Studies, Vol. 23, No. 9, 764-775, 2013. doi: 10.1080/10511970.2012.740770

[29] S. Y. Hwang. Rethinking creativity: Present in expression in creative learning communities. Educational Philosophy and Theory, Vol. 49, No. 3, 220-230, 2017. doi: 10.1080/0013 1857.2016.1225559

[30] T. Kettler, K. N. Lamb, A. Willerson, D. R. Mullet. Teachers' Perceptions of Creativity in the Classroom. Creativity Research Journal, Vol. 30, No. 2, 164-171, 2018. doi: 10.1080/10400419.2018.1446503

[31] H. Zacher, E. Johnson. Leadership and creativity in higher education. Studies in Higher Education, Vol. 40, No. 7, 1210-1225, 2015. doi: 10.1080/03075079.2014.881340

[32] I. Jahnke, T. Haertel, J. Wildt. Teachers' conceptions of student creativity in higher education. Innovations in Education and Teaching International, Vol. 54, No. 1, 87-95, 2017. doi: 10.1080/14703297.2015.1088396

[33] P. A. Rodgers, P. Jones. Comparing University Design Students' and Tutors' Perceptions of Creativity. The Design Journal, Vol. 20, No. 4, 435-457, 2017. doi:10.1080/14606 925.2017.1323503

[34] A. V. Kirillov, N. P. Li, M. V. Vinichenko, A. V. Melnichuk, T. K. Ridho. Role of corporate culture in efficient performance of the talent pool in the organization. Opciyn, Aco, Vol. 34, No. 85, 956-973, 2018.

[35] M. Selkrig, K. Keamy, K. Creative pedagogy: a case for teachers' creative learning being at the centre. Teaching Education, Vol. 28, No. 3, 317-332, 2017.doi:10.1080/104 76210.2017.1296829

[36] G. J. Puccio, C. Burnett, A. Selcuk, J. A. Yudess, M. Holinger, J. F. Cabra. Creative Problem Solving in Small Groups: The Effects of Creativity Training on Idea Generation, Solution Creativity, and Leadership Effectiveness. Journal of Creative Behavior. 2018. doi: 10.1002/jocb.381 Online available fromhttps://onlinelibrar y.wiley.com/doi/10.1002/jocb.381Accesseddate03.10.2018

[37] A. V. Kirillov, M. V. Vinichenko, A. V. Melnichuk, Y. A. Melnichuk, M. V. Vinogradova. Improvement in the learning environment through gamification of the educational process. Iejme, Mathematics Education, Vol. 11, No. 7, 2071-2085, 2016.

[38] Belousova, A.A., Gurianov, P.A., Melnichuk, A.V., Vinichenko, M.V., Duplij, E. (2016). Dividend Payments and Cross-country Differences in the Choice of Dividend. International Journal of Economics and Financial Issues, 6 (S1): 46-51.

[39] L. Sondergaard, M. Murthi. Skills, not just diplomas. Managing education for results in Eastern Europe and Central Asia. World Bank 2012. Online available from http://siteresources.worldbank.org/ECAEXT/Resources/10 1411_FullReport.pdf Accessed date 03.10.2018.

[40] What are the requirements of employers to young professionals. Website of the Internet portal Career.ru. 2016. 
Online available from https://career.ru/article/18255 Accessed date 03.10.2018.

[41] E. P. Tavokin. Russian youth in the labor market in the expert assessments. Monitoring of Public Opinion: Economic and Social Changes, Vol. 2, 175-184, 2016.

[42] Higher education: control should not be weakened, quality should be improved. Russian Public Opinion Research Center website. 2016. Online available from https://wciom.ru/index.php?id=236\&uid=115775 Accessed date 03.10 .2018 .

[43] A. N. Zhilyaev, A. I. Oleynik. Actual problems of preparation and developments of personnel potential in IT branch. Quality, innovations, education, Vol. 12, 9-23, 2015.

[44] Why Soft Skills Beat Hard Skills In Business, (2016). Online available fromhttps://www.huffingtonpost.ca/evan-thomps on/soft-skills-win-in-business b 9902570.html Accessed date 03.10.2018.

[45] On the quality of higher education. Website of the Public Opinion Fund. 2012. Online available fromhttp://fom.ru/N auka-i-obrazovanie/10516 Accessed date 03.10.2018.

[46] Student 2017: eagerness to study and employment prospects. Russian Public Opinion Research Center website. 2017. Online available from https://wciom.ru/index.php?id=236 \&uid=116041 Accessed date 03.10.2018.

[47] Higher School: desirable and undesirable innovations. Public Opinion Foundation website. 2014. Online available from http://fom.ru/blogs/11515 Accessed date 03.10.2018.

[48] O. V. Rogach, E. V. Frolova, A. V. Kirillov, V. V. Bondaletov, M. V. Vinichenko. Development of favourable learning environment and labor protection in the context of harmonization of social interaction of educational system objects. IEJME - Mathematics Education, Vol. 11, No. 7, 2547-2558, 2016

[49] T. S. Demchenko, M. V. Vinichenko, M. V. Demchenko, I. Y. Ilina, N. V. Buley, E. V. Duplij. Students' Satisfaction with Interactive Forms of Training with Elements of Gamification. International Journal of Engineering \& Technology, Vol. 7, No. 4.38, 109-111, 2018. 